\title{
FORMATION OF COMPETENCES OF FUTURE EDUCATORS FOR REQUIREMENTS EDUCATION FOR SUSTAINABLE DEVELOPMENT
}

\author{
OKSANA KONDUR, HALYNA MYKHAILYSHYN, NATALIIA RIDEI, OKSANA KATSERO
}

\begin{abstract}
With the help of analysis the recommendations of major international conferences, treaties and conventions over the last two decades of reforming the education system for sustainable development have substantiated that the range of scholars interested in addressing the issues of progress towards sustainability has expanded from economists to scientists and economists. Businessmen, educators and representatives of governments, politicians, managers who are trying to bring sustainable development ideas into practice with all stakeholders. Attention is directed to finding new solutions to the problems of sustainability of the biosphere and society. The main solution to the problems is the formation of national educational systems for sustainable development, which should include environmental, social and economic, organizational and managerial aspects of shaping the quality of training of specialists and the quality of life of humankind, using formal, non-formal inclusive democratically oriented models of education and science. In all areas with public awareness, broad access to education and a reorientation of the entire education system to take into account sustainable issues of development.

Education for sustainable development should be at the forefront of the concepts and strategies for moving towards sustainability, which provided for the development of a National action plan for the implementation of the United Nations Strategy for education for sustainable development. It is established that activities to disseminate his ideas will help to improve the quality of education and to implement the principles of "Education for All". Sustainable development issues should be included more actively in higher education institutions (HEI) curricula and science, at all levels to promote the formation of a national education system for sustainable development, and to formulate five- and ten-year framework programs and National action plans for the implementation of the UN Strategy. Transformation of HEI curricula and curriculum, primarily those providing pedagogical education, to form sustainable development competencies for future and contemporary teachers (academics) should be a priority of the National Action Plan for the implementation of the Strategy. We describe the basic requirements for the preparation of a modern teacher who would possess communication managerial, qualitative competencies.
\end{abstract}

Keywords: competence, pedagogical education, education for sustainable development, professional training.

\section{INTRODUCTION}

The purpose of education is closely linked to the goals set by society in its development and the individual in the individual and social life. The life of the individual in particular and of society in 
general is determined by education and upbringing. At the same time, education and upbringing affect social life. To understand the system of education and upbringing of a certain society means to understand the structure of its life and development strategies.

Education is the main prerequisite for achieving sustainable development. It is an effective tool for social, economic, environmental management and the development of democracy. The restructuring of education systems in each country should focus on promoting the development of creative thinking among the population, fostering tolerance, understanding democratic forms, making informed decisions and participating in the implementation of cross-cutting plans.

The importance of transitioning the world community to sustainability was first announced at the Earth Summit (1992). In this forum, education is recognized as a social mechanism and the main way of implementing the principles of sustainable development [1]. The modern concept of Education for Sustainable Development (ESD) is based on the "Agenda for the XXI-st century, adopted by the governments of the leading States in 1992 at the United Nations Conference on the Environment [8]. On the basis of this document, the formation of ESD is coordinated as a separate educational and scientific geotranscontinental socio-economic area [5]. Therefore, the training of future professionals in all industries should be based on the basic ideas of education for sustainable development.

\section{ANALYSIS AND Discussion}

The importance of education in general for sustainable development in their scientific works are considered by V.M. Bogolyubov [3], L.G. Melnyk [21] N.N. Moiseyev [12], N.M. Ridey and Yu. A.Kucherenko [17], A. D. Ursul and A. L. Romanovich [26], and others. The scientific team under the guidance of M.Z. Zgurovsky developed in [22] a method for measuring the processes of sustainable development of Ukrainian regions, taking into account economic, social and environmental dimensions.

The 2005 ESD Regional Strategy for the United Nations Economic Commission for Europe (ESD) prioritized action to transform learning environments by integrating sustainable development principles into education and educational establishments. The ESD strategy envisages a transition from simple transfer of knowledge and skills to preparing people (especially managers) to systematic actions of the organization of socio-economic development planning, management decision-making and responsibility in maintaining the sustainability of social establishments. The main task of ESD education is the formation of noospheric consciousness of people, the need to ensure a coherent way of life with the principles of sustainable development (to be more informed, moral and responsible about the ability of future generations to please their needs, where the education is based on moral and ethical values .

Competences in the field of education for sustainable development were adopted at the sixth meeting of the United Nations Economic Commission for Europe (UNECE) in 2011 [24]. The role of the social component in shaping the strategy of transition of society to sustainable development is more important than the economic one.

The National Strategy for the Development of Education in Ukraine for the period to 2021 [10] declared the introduction of sustainable development aspects into the educational system of Ukraine. The content of education should focus on sustainable development goals. Therefore, it is necessary to increase the accessibility of quality, competitive education, innovativeness of transition of society to sustainable development and ensuring personal development of every citizen; integration of the modernized national education system into the world educational and scientific space. To achieve these goals the following steps are implied:

- reforming educational systems based on "human-centrism" as a strategy of national education and science;

- improving the quality of education and research on an innovative basis;

- ensuring the accessibility and continuity of education throughout life;

- implementing a competency-based approach to sustainability; 
- creation of legal framework of educational and scientific systems;

- implementation of a variety of educational models, social and educational establishments;

- educational modeling of different types and forms of property, forms and means of obtaining education, as well as patriotism;

- development of scientific and innovative activity on condition of informatization of education.

The objectives for higher education are to establish a legal framework to motivate employers to cooperate with HEIs, to participate in the development of higher educational standards, to provide bases for students to pass internships and the first workplace for graduates; re-equipping the educational, scientific, methodological and material base of the HEIs through targeted financing.

The development of the educational system is also based on the recommendations of of the New Strategic Program for European Cooperation "Education and Training 2020", aimed at building informationoriented European societies and lifelong learning and access for citizens [11]. The program prompted "the creation of regulatory, methodological, scientific, methodological, educational and technical support for the education system, which takes into account the assessment of the quality and effectiveness of educational and upbringing activities of educational establishments, counseling system, scientific expertise of specialists of NAS, NAPS of Ukraine, other scientific establishments" [13].

The UN General Assembly Sustainable Development Summit (New York, USA, 2015) adopted the New Goals [25]. Sustainable Development Goals National Report: Ukraine "[14] contains 17 sustainable development goals for Ukraine by 2030, including [23]:

- to bring to end global poverty through education and research,

- to ensure healthy lifestyles and quality of life for all categories through scientific research on the methodology for shaping quality of life and the environment).

- to guarantee quality management of educational systems and to promote lifelong learning and research by 2030;

- to achieve gender equality in ensuring the rights of girls and women in education and research in research, professional development, as well as self-realization and self-improvement throughout life;

- ensure sustainable economic growth, employment over a lifetime (including education and science workers);

- to promote infrastructure, sustainable industrialization and innovation (Ukraine has committed itself to achieving the goals of the education-science-production chain);

- "to strengthen the means of achieving sustainable development and to enhance the work of the Global Partnership Mechanisms for Sustainable Development" [ 25].

The model of civilization development of the III millennium is formed through the mechanism of education and science system for sustainable development. Education for sustainability is evolving on a geospheric, geopolitical, transboundary scale. In the light of the adoption of the new "transformative" Agenda for Sustainable Development by 2030 and the new UN and UNESCO Sustainable Development Education documents [6], including the Global Program for Action on Sustainable Development Education [18], it is important to understand their meaning and prospects. The fourth objective at the UN and UNESCO is recognized as the new conceptual paradigm of education and science, the quality of life of people through the promotion of education, its role as a driving force for development and in achieving other goals. The prioritization of this goal from the Sustainable Development Goals does not mean that others are not relevant to the subject area of education for sustainable development. The development of Education for Sustainable Development encourages the implementation of a new strategy for the global education process. In particular, the task is to significantly increase the number of qualified teachers, including through international cooperation in teacher training.

The overarching goal of the UN Strategy is to encourage States to integrate elements of sustainable development education into their formal and non-formal education systems within all relevant disciplines. This is also mentioned in the final document of the Rio +20 Summit. In order to achieve this goal, it is necessary to solve the problems of expanding the sphere of knowledge of future specialists, development of their special skills, intelligence, formation of active life position and moral and ethical 
values, transition to sustainable development through directed modernization of formal and nonformal education.

On the basis of such global requirements for education, the need for future educators is justified and it is necessary to acquire knowledge that will enable them to integrate sustainable development issues into curricula and programs in different disciplines. The governments of countries should promote the availability of educational tools, teaching aids and textbooks for sustainable development to all who need them.

The concept of national education for sustainable development of Ukraine [3] is focused on fundamental principles, thematic programs and ways of solving problems of transition of society to sustainable development. It is based on interdisciplinary and multidisciplinary approaches, a systematic methodology for the integrity of learning, research, innovation and development, a balance of social, environmental, economic and engineering educational systems (various forms of basic and additional education, integrated network, distance).

The transition of society to sustainable development should be seen as a continuous process of learning and research, of transformation of all subjects of formal, non-formal and inclusive education. Therefore, appropriate qualitative changes are needed in the methodology for the formation of competencies in the field of sustainable development among leaders (civil servants and politicians), specialists and, first of all, teachers of educational establishments of all levels. In the Ukrainian education system, the following primary steps should be taken at all levels of the formal and nonformal education system [3]:

- introduce in general educational institutions teaching disciplines and programs incorporating aspects of education for sustainable development;

- at the level of vocational education to bring the issue of sustainable development to the industry standards, training and research programs,

- at the level of higher education, in the development and implementation of new standards, make mandatory general competences for sustainable development in the normative component with their corresponding filling of interdisciplinary content modules;

- to develop appropriate educational-methodological and scientific-methodical, informationreference, logistical, telecommunication support (training programs, textbooks and manuals on sustainable development) of educational, research, management processes;

- in the field of training and advanced training pedagogical and scientific-pedagogical staff on education for sustainable development to ensure the progress of the system of training and retraining of teachers, scientists and managers of all levels of categories in the field of sustainable development management, and to include its principles in the curriculum and scientific programs institutions of postgraduate (continuing adult education) pedagogical education;

- to scientifically substantiate the National Sustainable Development Strategy of Ukraine and to ensure its implementation at the legislative level in the field of scientific research and the development of international cooperation; to determine the formation of a national program of scientific research in the field of education management for sustainable development with the involvement of NAPE, HEI staff, teachers and public figures as one of the priority directions of the development of national science; to guarantee the state support of the system of scientific support of realization of the basic tasks in educational institutions.

The main task of education for sustainable development is the formation of a value-oriented personality (oriented towards socially and environmentally significant values). Therefore, in the process of developing a national action plan for the implementation of the UNECE Education Strategy for Sustainable Development, an axiological approach is of particular importance, which involves changing the structure of values of modern society, the connections of different values among themselves, between social and structural factors and human personality. Attention is drawn to the promotion of advocacy and the implementation of sustainable development ideas in social networks. In particular, there are many groups on facebook discussing the implementation of education ideas for sustainable development in different countries and in different types of educational institutions. 
Among them, the most active are the Innovative Developmental Education groups, Sustainability Education Group, Education for Sustainable Development, SEAE Research Cluster (Sustainability, Environment \& the Arts in Education), Education for Sustainable Development, Information Platform "Education for Sustainable Development", Early Childhood Education for Sustainability and others. These Sustainable Development Education Teams have been created by researchers from different countries. Their purpose is to exchange understanding, experience and resources that will help to integrate sustainable development goals into formal education.

The National Strategy for the Development of Education in Ukraine (until 2021) regulates the introduction of aspects of sustainable development into the educational system of Ukraine by orienting the content of education in accordance with the goals of sustainable development. The main goal is to ensure the availability of quality, competitive education, personal development of each citizen. Within the framework of the international project "Education for Sustainable Development in Action", a set of manuals and programs of "Lessons for Sustainable Development" courses have been developed for teachers and students of grades 1-10, for which the MESU was awarded [15].

The new higher education standards for the various fields and specialties provide for the priorities of the Strategy - with the mandatory inclusion of common multidisciplinary competencies in managing sustainability. The task of educational establishments, especially universities, is to form a new generation of specialists for the national and international economy. These should be people with an innovative type of thinking, an innovative kind of culture, ready to innovate. That is, the results of transformations in education should affect the development of the economy and society as a whole.

Experts in the field of education for sustainable development argue that teachers are extremely important drivers of change in the educational system as a whole, and in particular in the education system for sustainable development [20]. Therefore, the transformation of curricula and curriculum into HEIs that provide pedagogical education should be a priority of the National Action Plan for the implementation of the Strategy. The main initiators of such changes should be the professionally trained heads of faculties and pedagogical universities [13]. It is necessary for the formation of competences for sustainable development in future and modern teachers (scientists)

In general, under pedagogical competence will be understood as a synthesis of cognitive, visual, practical and personal experience. In the conditions of decentralization of education, increasing the level of autonomy of educational establishments, it is important to involve teachers in management processes in order to constantly improve the organization and content of the educational process. This should be taken into account when preparing pedagogical staff, namely: a student who obtains a pedagogical specialty must have modern theories and methods of management in educational systems, while clearly realizing that "management" equal to "responsibility".

The Sustainable Development Education Competency Model for Educators was formed in the Austrian research project Competences for ESD in Teacher Education. It is part of a large-scale project of the European Union. Education cannot be detached from society. The task of teachers is to shape the next generation so that they want and have the opportunity to participate in shaping society.

In [9], David Koonsley formulated the requirements for a pedagogical vision of education for sustainable development:

- optimism: based on sustainable development concepts, explaining complex facts to students and reinforcing the belief that problems can be solved. Sustainable development does not deny problems, but presents them as fundamentally managed. This will help to generate optimism for the youth in the future.

- pluralism though reality is complex and multifaceted, the pedagogical vision should not offer a one-sided view. Here, the concept of a regulatory idea is an appropriate benchmark for sustainable development.

- integrity: although the social perspective is shifting to the pedagogical level, education is only one dimension of sustainable development. It must be taken into account at the same time as political and social transformations. 
Education for sustainable development is not aimed at changing people's lifestyles, but at "empowering and encouraging them to participate in sustainable development, to reflect on their actions in this field" [9, p. 30].

Future educators need to develop: general knowledge of the content of sustainable development (which they will then pass on to students) and education for sustainable development; ability to combine the content of different disciplines in terms of social and cultural context [19]. An educational provider must be able to explain to the educator that knowledge is a culture and a value, and to learn to overcome uncertainty. Students need to form critical thinking, ability to respond to different situations, resolve conflicts, work as a team, develop responsibility and autonomy, the tools of strategic thinking. After all, sustainable development is an optimistic concept. That is, it is important not only to identify and respond to the problems of today, but also to be able to anticipate.

The implementation of the reform of secondary education "Modern Ukrainian School" poses new requirements for the professional competence of teachers, which necessitates the improvement of the content of pedagogical education, in particular in filling it with modern educational management. Future educators should have communication and management skills. Planning and organization enable them to create favorable learning conditions in their educational institutions and to provide opportunities for students to study in out-of-school educational establishments. It will be a collaboration between education and the social environment.

Though quality is a hallmark of sustainable development, future educators also need to build qualitative competence to ensure the quality of the educational process at different educational levels. We described it in more detail in $[2 ; 7]$.

\section{CONCLUSIONS}

Sustainable development is an important component of modern educational development. The education industry must develop skills for the young generation to create humans living conditions both locally and globally. To do this, the teacher must be able to form communication competences in youth, independence, self-determination, responsibility for oneself and society in general.

According to Rauch F. and Steiner R. in [16], education for sustainable development has various manifestations, such as "ecological education, civic education, global education, peaceful education, medical education, consumer education, and more," and therefore, "sustainable future design can be linked to education". What encourages future educators to form strategic, critical and innovative thinking, as well as communication, managerial and qualitative competences in their future education.

\section{REFERENCES}

[1] Agenda for the 21st Century. Translation from English. Intelsphere, Kyiv, 2000. (in Ukrainian)

[2] Budnyk O., Kondur O., Mykhaylyshyn G., Ridei N. The diagnostics of administrative and qualitological competencies of students in HEE. Open educational e-environment of modern University. Special issue "New pedagogical approaches in STEAM education", 2019, 32-43. doi: 10.28925/2414-0325.2019s4 (in Ukrainian)

[3] Bogolyubov V.M. Conceptual approaches to the formation of education for sustainable development. Collection of Scientific Articles of the International Scientific and Practical Conference "II-All-Ukrainian Congress of Ecologists with International Participation (Ecology-2009)", Vinnitsa, September 21-24, 2011 FOP Danilyuk, Vinnytsia, 2011, 665-668. (in Ukrainian)

[4] Bondar O.I, Tymochko T.V, Marushevsky G.B, Bilyavsky G.O, Satalkin Y.M The concept of national education for balanced development. Proceedings of the All-Ukrainian Scientific Ecological Conference, October 26, 2010, Kyiv. Center for Environmental Education and Information, 2010. (in Ukrainian) 
[5] Green Andy. Education, Globalization and the Nation State. In: Education, Globalization and the Nation State. Palgrave Macmillan, London, 1997. doi: 10.1057/9780230371132_8

[6] Incheon Declaration - Education-2030: Ensuring universal inclusive and equitable quality education and lifelong learning. Available at: https://unesdoc.unesco.org/ark:/48223/pf0000233137_rus (in Russian)

[7] Kondur O. Quality Management of Educational Systems in Globalization Conditions: theory, organization methodology, practice. NAIR, Ivano-Francivsk, 2018. (in Ukrainian)

[8] Konferenz der Vereinten Nationen für Umwelt und Entwicklung. Rio de Janeiro, 1992. Available at: http://www.un.org/depts/german/conf/agenda21/agenda_21.pdf

[9] Knzli-David C. Zukunft mitgestalten. Bildung für eine Nachhaltige Entwicklung - Didaktisches Konzept und Umsetzung in der Grundschule. Haupt, Berne, 2007. (in German)

[10] Law of Ukraine "On the National Strategy for the Development of Education in Ukraine for the Period up to 2021" of 25.06.2013 No. 344/2013. Available at: https://zakon.rada.gov.ua/laws/show/344/2013 (in Ukrainian)

[11] Law of Ukraine "On the Fundamental Principles (Strategy) of the State Environmental Policy of Ukraine for the Period up to 2020". Verkhovna Rada of Ukraine, 2011, No. 26, Art. Approved by the VRU on December 21, 2010. No. 2818-VI. Available at: https://zakon.rada.gov.ua/laws/show/2818-17 (in Ukrainian)

[12] Moiseev N.N. On the necessary features of civilization of the future (Philosophical notes). In: Nikitin A.T., Stepanova S.A. (Eds.) Ecology, nature protection, ecological safety: a textbook for the system of professional retraining and advanced training of civil servants, managers and specialists of industrial enterprises and organizations. MNEPU, Moscow, 2000. (in Russian)

[13] Ridey N.M., Sergienko V.P. (Ed.) Multimodus Foundations of Postgraduate Education for Sustainable Development. NPU named after M.P. Drahomanov, Kyiv, 2017. (in Ukrainian)

[14] National report "Sustainable Development Goals: Ukraine". Available at: http://www.un.org.ua/images/SDGs_NationalReportUA_Web_1.pdf (in Ukrainian)

[15] Pometun O.I. and others. Preparing Teachers for Sustainable Development Teaching: Teaching Methodological Materials for Higher Educational Teachers. institutions and systems of postgraduate pedagogical education. Pedagogichna dymka, Kyiv, 2015. (in Ukrainian)

[16] Rauch F., Steiner R. Competitions for education for sustainable development in teacher education. CEPS Journal, 3 (1) (2013), 9-24. urn:nbn:de:0111-opus-76634

[17] Ridey N.M, Kucherenko Yu.A. Indicator of sustainability of development of relations between society and nature - ecological culture. Taurida Scientific Herald, 91 (2015), 180-200. Available at: http://www.tnv-agro.ksauniv.ks.ua/archives/91_2015/38.pdf (in Ukrainian)

[18] Roadmap for the implementation of the Global Program of Action for Education for Sustainable Development. Available at: http://unesdoc.unesco.org/images/0023/002305/230514r.pdf (in Russian)

[19] Steiner R. Kompetenzorientierte Lehrer/innenbildung für Bildung für Nachhaltige Entwicklung. Monsenstein \& Vannerdat, Munster, 2011. (in German)

[20] Sleurs W. (Ed.) Competencies for ESD (Education for Sustainable Development) teachers. Comenius 2.1 project 118277-CP-1-2004-BE-Comenius-C2.1.

[21] Melnik L.G. Sustainable Development: Theory, Methodology, Practice. Unyversytetskaia Knyha, Sumy, 2009. (in Russian)

[22] Zgurovsky M.Z. Sustainable Development of the Regions of Ukraine. NTUU "KPI", Kyiv, 2009. (in Ukrainian)

[23] Sustainable Development Strategy of Ukraine until 2030. Available at: http://sd4ua.org/wpcontent/uploads/2015/02/Strategiya-stalogo-rozvytku-Ukrayiny-do-2030-roku.pdf (in Ukrainian)

[24] United Nations. Learning for the future: competence in the field of education for sustainable development. ECE/CEP/AC.13/2011/6.

[25] United Nations. Sustainable Development Goals. Available at: http://www.un.org/sustainabledevelopment/en/summit/

[26] Ursul A.D., Romanovich A.L. Security through Sustainable Development. Available at: http://spkurdyumov.ru/economy/bezopasnost-cherez-ustojchivoe-razvitie/2/ (in Russian) 
Address: Kondur Oksana, Mykhailyshyn Halyna, Vasyl Stefanyk Precarpathian National University, 57, Shevchenko Str., Ivano-Frankivsk, 76018, Ukraine;

Ridei Nataliia, Katsero Oksana, National Pedagogical Dragomanov University, 9, Pyrohova Str., Kyiv, 01601, Ukraine.

E-mail: oksana.kondur@pnu.edu.ua, halyna.mykhailyshyn@pnu.edu.ua, nataliia.ridei@gmail.com, o.katsero@gmail.com

Received: 10.01.2020; revised: 18.02.2020.

Кондур Оксана, Михайлишин Галина, Рідей Наталія, Кацеро Оксана. Формування компетентностей майбутніх педагогів на вимоги освіти для сталого розвитку. Журнал Прикарпатського університету імені Василя Стефаника, 7 (1) (2020), 7-14.

Проведено аналіз рекомендацій головних міжнародних конференцій, договорів і конвенцій реформування системи освіти для сталого розвитку за останні два десятиліття. На основі нього обгрунтовано розширення стейкхолдерів у питанні поступу до сталості: від науковців-екологів та прогресивних економістів, бізнесменів, педагогів, представників урядів, політиків, управлінців. Всі вони намагаються об'єднати ідеї сталого розвитку на практиці. Найбільша увага спрямовується на пошук нових рішень проблем стійкості біосфери і суспільства. Одним із шляхів вирішення даної проблеми є формування національних систем освіти для сталого розвитку. Вони повинні включати екологічні, соціальні та економічні, організаційно-управлінські аспекти формування якості підготовки фахівців та якості безпеки життя людства. При цьому слід використовувати формальні, неформальні, інклюзивні, демократично орієнтовані моделі організації освіти та науки. Також забезпечувати доступ до освіти широких верств населення, орієнтувати системи освіти на врахування проблематики сталого розвитку. Тому освіта для сталого розвитку має посісти провідне місце в концепціях і стратегіях поступу до сталості. В українській освітній системі слід активніше вкдючати проблематику зі сталого розвитку до навчальних та наукових програм 3ВО, на всіх рівнях сприяти формуванню національної системи освіти для сталого розвитку. Трансформація навчальних планів ЗВО і програм навчальних дисциплін, в першу чергу таких, що надають педагогічну освіту, для формування компетентностей зі сталого розвитку в майбутніх і сучасних викладачів (науковців) мають стати пріоритетом Національного плану дій з реалізації Стратегії ООН зі сталого розвитку. Нами описано основні вимоги до підготовки сучасного педагога відповідно до ключових завдань освіти ддя сталого розвитку. Адже завдання освітян полягає у формуванні наступних поколінь, які хотіли та мали можливість брати участь у побудові суспільства сталого розвитку. Тому майбутні педагоги повинні володіти комунікаційними та управлінськими навичками для співпраці освітньої галузі та соціального середовища.

Ключові слова: компетентність, педагогічна освіта, освіта для сталого розвитку, фахова підготовка. 